\title{
Interspecies Literature: Clarice Lispector's Zoophytographia
}

\author{
PATRÍCIA VIEIRA \\ Georgetown University \\ Centro de Estudos Sociais da Universidade de Coimbra
}

\begin{abstract}
This essay analyzes the role plants and animals play in Clarice Lispector's work. I argue that Lispector often stages a face-to-face encounter with non-humans to trigger a process of defamiliarization, whereby our anthropocentric values and norms come undone. I discuss exemples of this encounter in short stories from Laços de Família and in the novel A Paixão segundo G.H. In these works, Lispector reflects upon concepts we usually take for granted, such as reason or language, a process that results in a profound transformation and extension of these concepts to our non-human others.
\end{abstract}

Keywords: Ecocriticism; plants and animals in literature; inhumanity; Laços de Família; A Paixão Segundo G.H.

"Não vou ser autobiográfica. Quero ser "bio."

(Lispector, Água Viva 30)

Clarice Lispector stated time and again that life, even in its humblest instantiations, trumps the most elaborate of texts. ${ }^{1}$ In "O Homem que Apareceu," part of the collection of short stories A Via Crucis do Corpo (1974), for instance, she stages the following dialogue: "Você jura que a literatura não importa? / - Juro, respondi com a segurança que vem de íntima veracidade. E acrescentei: qualquer gato, qualquer cachorro vale mais do que a literatura"

\footnotetext{
${ }^{1}$ Patrícia Vieira, holder of an FCT Researcher grant from the Portuguese Foundation for Science and Technology (IF/00606/2015), gratefully acknowledges this institution's financial support under the Strategic Project UID/SOC/50012/2013.
} 
(Contos 165). Far from a belittlement of animals, this conversation should be read literally as an acknowledgment that texts are only a way to reach out to the world, a window through which we can contemplate reality. Or, as I argue in the present essay, that literature is one of the many forms of expression used by living beings, which writers incorporate into their aesthetic praxis. Lispector attributes pride of place to non-humans in the exploration of reality's enigmas, the ultimate goal of her work. Cats and dogs are not only worth more than literature but she also finds in them, as well as in other animals and plants, the main source of her reflections on existence. It is through our manifold relations with our others that we come to understand our co-belonging in the continuum of life. Plants and animals are Lispector's guides toward this immersion into life, co-writers of her texts, where they inscribe their modes of being, therefore redefining what it means to be human.

I define the imbrication of plants and animals in literature as zoophytographia, or interspecies writing. ${ }^{2}$ The idea that a literary text can be co-written by non-humans appears at first to be a fanciful notion, to say the least. After all, human cultural productions can hardly escape an anthropocentric framework determined by our way of experiencing the world and by our long history of coexistence, interaction with, and exploitation of vegetal and animal beings. We are able, at most, to ventriloquize the voices of flora and fauna to convey what we think they might say if their worldview was indeed ever translated into verbal language, an imaginary speech that projects our desires and aspirations upon others. At the same time, plants and animals have their own way of expressing themselves, a language that remains, for the most part, inaccessible to humankind. ${ }^{3}$ Still, some texts attempt the perilous crossing of the chasm separating our standpoint from that of non-humans. They strive to approach plant and animal life and to integrate their specific being-inthe-world into literature. Such a literary face-to-face with the lives of others yields two different but complementary outcomes: on the one hand, it triggers a probe into the very meaning of humanity and of life itself; on the other hand, it pushes written language to the limits of the unutterable, as literature is contaminated by non-verbal forms of expression.

\footnotetext{
${ }^{2}$ For an in-depth, theoretical discussion of this notion, see Vieira.

${ }^{3}$ See Galiano, Ryan, and Vieira for recent scientific studies on the language of plants, as well as philosophical reflections on plant language and literary criticism on this subject.
} 
Vieira

Widening the boundaries of literature to encompass the existence and expression of animals and plants, zoophytographia enriches human experience, cracking open the edifice of anthropocentrism to let others in and to allow humanity to peek out. But interspecies writing is not without its pitfalls. The risk of exerting violence over flora and fauna, superimposing our preconceptions onto them and thus preventing them from speaking at the very moment when one lends them a voice, is very real. Zoophytographic writing springs from the belief that literature can propitiate an encounter with the lives of non-humans that does not necessarily entail subsuming them onto our own parameters. An encounter that does not involve conquest but operates though a give and take, transforming each party in the process and resulting in a novel literary language. Lispector's texts provide examples of such a transformative literary undertaking.

\section{Plant and Animal Encounters}

Lispector wants to avoid humanizing animals and to impose our constraints upon them. In one of her crónicas, she censures a man who has domesticated a coati, treating the wild animal as if it were a dog and walking it on a leash. She imagines herself asking the man: "por que é que você faz isso? que carência é essa que faz você inventar um cachorro? e por que não um cachorro mesmo, então? [...] Ou você não teve outro modo de possuir a graça desse bicho senão com uma coleira? mas você esmaga uma rosa se apertá-la com força!" (Para não Esquecer). The animal is destroyed by its domestication, being reduced to a ridiculous shadow of its former, wild self: "aquele bicho já não sabia mais quem ele era" (Para não Esquecer). Lispector envisions the moment when the coati realizes that it has been denatured, corrupted by the whims of the man: "Mas se ao quati fosse de súbito revelado o mistério de sua verdadeira natureza? [...] Bem sei, ele teria direito, quando soubesse, de massacrar o homem com o ódio pelo que de pior um ser pode fazer a outro ser-adulterarlhe a essência a fim de usá-lo" (Para não Esquecer). She finds the drive to tamper with and mold animal nature to human needs an abhorrent cruelty. It debases the animal and, at the same time, demeans the humans responsible for such acts.

The episode with the coati exemplifies the opposite of what Lispector 
hopes to achieve in her writings on plants and animals. Instead of alienating flora and fauna, forced by humans to pose as something they are not, the author hopes to alienate human beings themselves, to defamiliarize our habits and social norms, viewed differently when considered from the prism of nonhumans. Wild animals cannot be tamed and turned into pets and even companion animals such as cats and dogs retain an irreducible foreignness, their most captivating feature, which the author hopes will contaminate humanity. This inversion of perspective comes through clearly in "The Crime of the Mathematics Professor" when the protagonist acknowledges: "Agora estou bem certo de que não fui eu quem teve um cão. Foste tu que tiveste uma pessoa" (Laços). The illusion of mastery over animals is shattered in the shortstory, as the main character recognizes that the influence his pet exerted over him was far deeper than whatever impact he had on the behavior of the animal: the professor was the one to be "possessed" by his dog, and not vice-versa. The man committed the "crime" of abandoning the animal to free himself from the pet's domination - "este crime substitui o crime maior que eu não teria coragem de cometer" (Laços), most likely the assassination of the animalonly to acknowledge his weakness in the end of the text.

For Lispector, this defamiliarization-Verfremdung, as Bertolt Brecht would have it - occurs when we are touched by the existence of plants and animals and compelled to contemplate our lives anew. The short-story "Amor," in Laços de Família (1960), portrays one such transformative brush with flora. The narrative revolves around a woman who experiences an existential crisis triggered by plants. It is set in the afternoon, at a time when, according to the narrator, "as árvores que plantara riam dela." Even though the trees in this quote are metaphorical-they refer to the routine, middle-class life of the woman: her growing children, the meals she prepares, her household-the scorn with which these everyday affairs laugh at her is sparked by real trees. The protagonist goes to a Botanical Garden where she contemplates the profound "decomposição" of "árvores carregadas" in an environment "tão rico que apodrecia." She reflects that "a moral do Jardim era outra" at odds with the petty bourgeois concerns that usually preoccupied her. Her encounter with the amoral proliferation of plants jolts her out of her drab existence, as she ponders the tranquil "crueza do mundo."

In "A Imitação da Rosa," another short-story from Laços de Família, 
Lispector turns once again to a face-to-face encounter with plants as a lifechanging event. The female protagonist, who suffers from an undetermined psychological illness, cannot resist the "beleza extrema" of a bunch of roses. The perfection of the flowers acquires religious undertones, as they are implicitly compared to Christ through the trope of imitatio. The woman feels that "quem imitasse Cristo estaria perdido - perdido na luz, mas perigosamente perdido," and this dissolution of self is what befalls her when she sits facing the flowers and gives in to their allure. Delivering herself, almost against her will, to the inhuman undertaking of imitating the perfection of the roses, she eventually abandons her conventional, prosaic existence and goes mad.

"O Búfalo," the final story of Laços de Família, goes back to another encounter with non-humans, this time with the titular animal. A woman goes to a zoo is search of a living being that might echo her anger: "Mas onde, onde encontrar o animal que lhe ensinasse a ter o seu próprio ódio?" She finally finds her match in a buffalo. Within the scopic regime that governs the zoo, a place where humans go to observe animals, the buffalo is the one living being who "faces" (encarou-a) the woman and returns her gaze: "Lá estavam o búfalo e a mulher, frente a frente. [...] Olhou seus olhos. E os olhos do búfalo, os olhos olharam seus olhos. [...] Olhos pequenos e vermelhos a olhavam. Os olhos do búfalo." The animal returns the woman's look, his silent "tranquil" (tranquilo) hatred for the humans who have imprisoned him a response to her own state of mind. The deep connection established between the woman and the buffalo, their encounter in the depths of their hatred for others, is what allows her to go through with her plan. She stabs herself to death, drawing her resolve from the calm strength of the animal.

The face-to-face encounters with plants and animals narrated in Lispector's short stories preclude a metamorphosis of the self into the other. Rather, the protagonists dwell in flora and fauna's difference, all attempts to imitate nonhuman existence a priori condemned to failure. The latent tension in these narratives results precisely from the elusiveness of plant and animal life that we encounter but can never completely grasp. Such a relationship to non-humans evokes the encounter with the Other that is the cornerstone of Emmanuel Levinas's philosophy. According to Levinas, the subject is constituted in the moment when the I faces the Other, who hails the I from its unbridgeable difference (Totality 33). Unlike what happens in a transformation, where the 
identification of the I with the Other is such that a transmutation of the one into the Other - of a human being into a plant or an animal, in Lispector's termstakes place, a face-to-face encounter is grounded upon detachment. For Levinas, the Other is unknowable and wholly separate from the I, who can therefore not empathize with the one facing it ("Transcendence" 151). Still, the subject is created by the call of the Other that, paradoxically, arrives from the most remote of distances but also originates within the self. Subjectivation takes place when the I recognizes the foreignness of the Other within, a formulation reminiscent of Lispector's ancestral call of animality mentioned above.

Even though the Levinasian Other is always a person, one could broaden this category to include non-humans (Calarco 55-77). In the work of Lispector, absolute transcendence - the Other, the highest, figurations of God - often comes full circle and incarnates in the most concrete, immanent and often abject being. The latter can be a plant or an animal, the encounter with which engenders a new human subject, all the while questioning the relation between divinity, humanity and non-humans.

\section{A Paixão Segundo G.H.}

One finds Lispector's best-known and most powerful example of a face-to-face encounter with a non-human Other in A Paixão Segundo G.H. (1964). ${ }^{4}$ The novel's first-person narrator, known only as G.H. —an acronym that can stand for "género humano," thus turning G.H. into an allegory for the whole of humankind (Williams 253) —, finds a cockroach inside the closet of a room formerly occupied by her live-in maid, and the novel works through the repercussions of this ostensibly mundane event. The encounter is at first framed by the "nojo" the protagonist experiences when she sees cockroaches, an "arcaico horror" that makes her feel repugnance whenever she is close to them (37). And yet, the woman's disgust will lead her to focus her attention on the

\footnotetext{
${ }^{4}$ For a Levinasian reading of A Paixão Segundo G.H., see Ballan. He argues that Levinas's work opens the door to an undecidability between absolute materiality and concreteness, on the one hand, and absolute distance and anonymity, on the other (540). For Ballan, this is exacerbated in the writings of Lispector; however, while Levinas never abandons an aspiration toward transcendence, Lispector tends to side with creatureliness and materiality, finding divinity in immanence (552-54).
} 
Vieira

cockroach and probe the source of her distaste for it. What ensues is a farreaching reflection on the roots of life that go far beyond the trappings of humanity.

After the initial shock of coming across a cockroach in her home, G.H. realizes that the animal is slowly crawling out of the closet and, overcome by an irrational fear, she tries to kill it by slamming a door against it. But the cockroach, although crippled, does not die. As she prepares to administer a final coup de grâce, G.H. encounters it face-to-face: "Mas foi então que vi a cara da barata. Ela estava de frente, à altura de minha cabeça e de meus olhos. [...] Mas eis que por um átimo de segundo ficara tarde demais: eu via. [...] Eu na verdade - eu nunca tinha mesmo visto uma barata. Só tivera repugnância pela sua antiga e sempre presente existência - mas nunca a defrontara, nem mesmo em pensamento" (43-44). ${ }^{5}$ The remainder of the text reveals the consequences of seeing the cockroach beyond the disgust that it usually elicits in humans. G.H. faces the animal concretely, in its corporeality, and in thought, to the point that the two modes of relating to it become one and the same, as the body and thinking are revealed to be both part of the ongoing becoming of life. ${ }^{6}$

Like the buffalo in the short-story discussed above, the cockroach reciprocates G.H.'s gaze with her "olhos [...] radiosos e negros. Olhos de noiva" (44). Later in the novel, she confesses: "Não sei se ela me via, não sei o que uma barata vê. Mas ela e eu nos olhávamos" (60). What transpires in this exchange of gazes upends the protagonist's worldview, exposing a realm of actuality that she did not suspect existed. It is worth transcribing the moment when the concrete sight of the animal metaphorically opens G.H.'s eyes to a hitherto unexplored dimension of life:

\footnotetext{
${ }^{5}$ Critics such as Benjamin Moser have argued that the pronoun "ela" is employed here because Lispector identifies the cockroach as female. G.H. points in this direction when she writes: "Eu só a [à barata] pensara como fêmea, pois o que é esmagado pela cintura é fêmea," 73). In general, A Paixão Segundo G.H. can be read as an attempt to condemn both anthropocentrism and phallocentrism, as Hilary Owen points out: "The displacement of the phallogocentric universe in A Paixão is at the same time the displacement of the anthropocentric universe" (176). A.M. Wheeler also establishes a link between animal imagery and gender roles in Laços de família.

${ }^{6}$ G.H. describes the appearance of the cockroach in detail: "Era uma cara sem contorno. As antenas saíam em bigodes dos lados da boca. A boca marrom era bem delineada. Os finos e longos bigodes mexiam-se lentos e secos. [...] A barata não tem nariz. Olhei-a, com aquela sua boca e seus olhos: parecia uma mulata à morte" (44).
} 
Mas se seus olhos não me viam, a existência dela me existia-no mundo primário onde eu entrara, os seres existem os outros como modo de se verem. [...] A barata não me via diretamente, ela estava comigo. A barata não me via com os olhos mas com o corpo. E eu-eu via. Não havia como não vê-la. Não havia como negar: minhas convicções e minhas asas se crestavam rapidamente e não tinham mais finalidade. [...] E nem podia mais me socorrer, como antes, de toda uma civilização que me ajudaria a negar o que eu via. (60)

What G.H. contemplates in her face-to-face with the cockroach is the animal's mode of existence, which is wholly disparate from her own. Unable to explain away the foreignness of the insect by resorting to the clichés spawned by an "entire civilization," the woman is forced to consider that life goes far beyond humankind. She realizes that the way of relating to others in Western culture, through seeing and objectifying, does not necessarily apply in the case of the cockroach, which interacts with its environment using its entire body. Once again, Levinasian thought is pertinent here. As the I, in his philosophy, cannot know the Other in its difference but finds traces of the Other within, so does G.H. recognize that the insect, which relates to her through its body, is at the same time inside her. The animal becomes a paradigmatic example of the uncanny, i.e., it is simultaneously alien and strangely familiar, which explains the revulsion mixed with attraction experienced by the protagonist when she first sees it (Nascimento 25). The cockroach's "being with" G.H. does not amount to a transformation of the human into the animal or vice-versa but a recognition that, despite the abyss separating the woman from the insect, they are able to relate to one another by the shared life that traverses them both. This is how we can read Lispector's idiosyncratic formulations: the cockroach's "existence existed me," since "beings exist other beings as a way of seeing each other." The cockroach "exists" humans insofar as both are living organisms, the former a much older species than the relative newcomer homo sapiens, and therefore inscribed in the phylogenic development of humankind.

What Lispector portrays in her fictional encounters between humans and non-humans is an immersion into the wellsprings of life. As G.H. deftly put it, what she saw in the eyes of the cockroach was "a vida me olhando" (45). Lispector refers to this primordial life by many different terms throughout her 
written work. G.H. calls it, among other things, "vida crua" (47), "mundo primário" (60), “o núcleo" (64), “o neutro" (67), "o nada” (73), and "matéria primordial" (81). In other works, she defines it as "vida primitiva" (Contos 83), "geleia viva" (Para não Esquecer), "neutro vivo das coisas" (Aprendizagem 100), "plasma" (Água Viva 9), "placenta" (Água Viva 9), and "the invisible nucleus of reality (Água Viva 20). These expressions point to a reality that antecedes humanness: "Eu sentia [...] que 'eu ser' vinha de uma fonte muito anterior à humana e [...] muito maior que a humana" (A Paixão 45); "diante da barata viva, a pior descoberta foi a de que o mundo não é humano, e de que não somos humanos. [...] o inumano é o melhor nosso" (A Paixão 55). ${ }^{7}$ Primordial life, of which the existence of the cockroach is just one of many instantiations, is about life's yearning for itself, a longing for being that is not yet differentiated into a specific individual. What is at stake is a depersonalized conatus essendi of life striving for existence, as Spinoza, one of Lispector's favorite philosophers, postulated in his Ethics (75). ${ }^{8}$ The face-to-face encounter with plants and animals reminds humans that they belong to this becoming of life that unites the living.

G.H. only draws the full consequences of her face-to-face encounter with the cockroach once she embraces "o inumano dentro da pessoa" (123). G.H. manages to "largar os sentimentos" (A Paixão 80) in the final pages of the text, when she eats a piece of the white paste oozing from the cockroach's crushed body. The Christian undertones are clear: much like the Eucharist, which bespeaks a communion with Christ, G.H.'s action signifies a togetherness with life itself, represented by the body of the insect. Once again, and like the Catholic ritual, eating part of the animal does not imply a metamorphosis. The woman and the cockroach remain thoroughly distinct, and tasting the latter's body as a Host is a token of this unbridgeable difference; literally, G.H. becomes a host to the body of the Other, a stranger in her home.

G.H. reflects that, by touching and eating a part of the cockroach, she has violated the Biblical injunction to avoid unclean beings. She speculates that unclean animals are those who have remained the same, without ornaments

\footnotetext{
${ }^{7}$ Later in the novel, G.H. adds: "Seremos inumanos_como a mais alta conquista do homem. Ser é ser além do humano" (134).

${ }^{8}$ According to Moser (122-23), Lispector's affinity for Spinoza is most clear in her first novel, Perto ao Coração Selvagem but his philosophy shapes all her work.
} 
ever since Creation (57). Here "o imundo é a raíz" (A Paixão 57), the true fruit of good and evil. The law forbids humans to experience this reality and keeps them in the sphere of things that live "disfarçadamente" (A Paixão 57), a protected realm that allows them to "construir uma alma possível" (A Paixão 57). By eating the unclean body of the cockroach, G.H. finds herself expelled from a "paraíso de adornos" (A Paixão 57) and thrown into pure life, a genuine, amoral paradise. A Paixão thus presents a challenge: to endure the suffering that comes with tearing the veils that mask actuality and embrace life beyond good and evil.

\section{Lispector's Interspecies Literature}

G.H.'s encounter with the cockroach teaches her that what she had hitherto called "humanness" was a shallow, false form of existence, a "grossa humanidade que sempre fora feita de conceitos grossos" (A Paixão 105). She writes that humanity is soaked in a fake humanization that precludes true humankind and its humanity (A Paixão 124). She reflects, "a pessoa é humana, não é preciso lutar por isso: querer ser humano me soa bonito demais" ( $A$ Paixão 123). Beyond this easy humanness, G.H. considers, "tinha que existir uma bondade tão outra que não se pareceria com bondade" (A Paixão 70).

G.H.'s critique of humanity does not spell out its complete rejection, however. She realizes near the end of the novel that what she is striving for is not a de-humanization but a more acute awareness of what being human actually means: “"não humano' é uma grande realidade, e [...] isso não significa 'desumano" (A Paixão 134). The trivial humanness of G.H.'s former life makes a mockery of genuine humanity, which is achieved only when we accept the inhuman within: "Enfim, enfim quebrara-se realmente o meu invólucro, e sem limite eu era. [...] O que não sou eu, eu sou. Tudo estará em mim [...]. Minha vida não tem sentido apenas humano, é muito maior [...] e só realizaria o meu destino especificamente humano se me entregasse [...] ao que já não era eu, ao que já é inumano" (A Paixão 40). One finds in this passage echoes of Spinoza, according to whom the difference between the I and its surroundings, as well as between body and soul, matter and mind, res extensa and res cogitans, is one of degree. True, all living beings are different, but they partake

of the same life principle and there is therefore no absolute divide separating 
the body of a cockroach from human thought. What is more, in the same way as the kernel of humankind can already be found in an insect, humanity also finds traces of all life forms in itself.

To be human is to become aware of the Other(s) within and to consciously accept it (or them). It is a return to primordial existence that does not completely dissolve in its originary amalgamation. It entails peeling back the layers of constructs we have created to obfuscate our proximity to plants and animals: "Havia recuado até saber que em mim a vida mais profunda é antes do humano" (A Paixão 105). This amounts simultaneously to a leap forward, to a humanness that knows of its kinship with the rest of the world: "Meu reino é deste mundo [...] e meu reino não era apenas humano. Eu sabia" (A Paixão 99). Genuine humanity is therefore a process of learning to be less and more than human: "Temos a liberdade de cumprir ou não o nosso destino fatal [...] de mim depende eu vir livremente a ser o que fatalmente sou. Sou dona de minha fatalidade e, se eu decidir não cumpri-la, ficarei fora de minha natureza especificamente viva. Mas se eu cumprir meu núcleo neutro e vivo, então, dentro de minha espécie, estarei sendo especificamente humana" (A Paixão 99). The specifically human mode of existence is to freely embrace the non-human others that inhabit our selves.

For Lispector, human language always falls short of her desire to commune with life. G.H. maintains that there is an "abismo entre a palavra e o que ela tentava [atingir]" (53) and, later in the novel, she reflects: "O nome é um acréscimo, e impede o contato com a coisa. O nome da coisa é um intervalo para a coisa" (110). Thre process through which humans get in touch with primordial life transpires in the "silêncio com que a vida se faz" (A Paixão 73) and in the "inexpressivo" (A Paixão 123), since "falar com as coisas é mudo" (A Paixão 126).

What then is the role of writing and literature in Lispector's existential thought? As the protagonist of Água Viva puts it:

[...] escrever é o modo de quem tem a palavra como isca: a palavra pescando o que não é palavra. Quando essa não palavra - a entrelinha - morde a isca, alguma coisa se escreveu. Uma vez que se pescou a entrelinha, poder-se-ia com alívio jogar a palavra fora. Mas aí cessa a analogia: a não palavra, ao morder 
a isca, incorporou-a. (19)

Literature is thus an attempt to capture the ineffable, knowing full well that one will never be completely successful in this endeavor. A certain word or expression may manage to "bait" the real and articulate it in language but it is unable to replace what is in its immediacy. Words can hope, at most, to be contaminated by life, which engulfs, incorporates and ultimately renders meaningless the language that strives to encompass it.

Before we write Lispector off as the ultimate anti-Derridean, striving for a mystic merging with a world above and beyond the triviality of language, we should pay closer attention to the fine grain of her prose. To be sure, she often expresses the belief that language is doomed to failure: "É exatamente através do malogro da voz que se vai pela primeira vez ouvir a própria mudez e a dos outros e a das coisas, e aceitá-la como a possível linguagem" (A Paixão 137). It is worth reflecting upon the nuances of this statement. On the one hand, entering the state of grace and communing with the world around us demands a breakdown of the voice, understood not simply as vocalized speech but as the whole of human language. But, on the other hand, this collapse of vocalization refers merely to human expression and not to language as such. As G.H. puts it a little further in the novel: "O indizível só me poderá ser dado através do fracasso de minha linguagem" (138; emphasis my own). It is the language of humanity, imbued with our preconceptions, that prevents us from understanding others as well as other things. We regard them as mute, passive beings at our disposal, because they do not share verbal communication with us. The challenge, for G.H., is to interpret the muteness of others and to recognize it as form of language.

In her reflections on language, Lispector addresses a distinction already outlined by Walter Benjamin. ${ }^{9}$ He argues that all beings and even things partake of language (72). Like Lispector, he sees verbal communication as only one possible mode of expression among many other mute languages of the world. However, he believes in the superiority of human language to name things, establish relations between them, and therefore release them from their enforced muteness, a capacity that has conferred upon humans the power to rule

\footnotetext{
${ }^{9}$ For a more in-depth discussion of Benjamin on language, see Vieira.
} 
over Creation (65). ${ }^{10}$ Lispector is less sanguine about human language. Contrary to Benjamin, she considers that verbalization is often a hindrance rather than an asset, preventing humanity from listening to the mute modes of expression of non-humans.

The final sentences of A Paixão can help us shed light upon Lispector's understanding of literature. The novel ends in an abrupt fashion, with G.H. considering the limitations of human language: "Pois como poderia eu dizer sem que a palavra mentisse por mim? como poderei dizer senão timidamente assim: a vida se me é. A vida se me é, e eu não entendo o que digo. E então adoro. - _ _ _ _ (141). The protagonist struggles with words that can lie and contrast with life's immanence and immediacy. The primordial life with which she comes into contact when she encounters the cockroach simply happens in/to and through her without words, at the breaking point of logos. The last words of the narrative, "E então adoro," denote a surrender to life, of which G.H. is in awe, and an abandonment of rational thought and verbal expression, signaled by the dashes. ${ }^{11}$

We shuld be clear, however, that Lispector, who wrote a number of novels, short-stories, and journalistic texts, is not exactly advocating for an end to verbal language and to literature. "O que sou então?" she asks in one of her crónicas published in Jornal do Brasil. "Sou uma pessoa que pretendeu pôr em palavras um mundo ininteligível e um mundo impalpável. Sobretudo uma pessoa cujo coração bate de alegria levíssima quando consegue em uma frase dizer alguma coisa sobre a vida humana ou animal" (Aprendendo). Literature is a way to articulate the muteness of the world and to say the unsayable: "Às vezes - às vezes nós mesmos manifestamos o inexpressivo - em arte se faz isso, [...] manifestar o inexpressivo é criar" (Aprendendo 112). Bordering on the ineffable, A Paixão, as well as many other of Lispector's texts, testify to literature's ability to push the boundaries of the unspeakable.

Literature is a paradoxical institution. It is made by and for humans using a verbal language only they can understand. But, at the same time, it aspires to

\footnotetext{
${ }^{10}$ As Benjamin puts it: "All nature, insofar as it communicates itself, communicates itself in language, and so finally in man. Hence, he is the lord of nature and can give names to things" (65).

${ }^{11}$ The novel also begins with the same set of dashes, suggesting that the narrative transpires in the middle of a process.
} 
overcome the constraints of its human origins and to express what is beyond humanity. It is not by chance that plants and animals figure so prominently in Lispector's fiction. Faced with the double bind of literary language, she turns to non-humans as her companions in the process of writing. To convey the muteness of the world, to go beyond human language and to articulate language as such, literature needs to include non-humans and their modes of expression. In other words, it needs to become a zoophytographia. Plants and animals are embedded in Lispector's literary language, transforming it from within. Her tendency towards impersonal grammatical constructions ("a vida se me é"), her simple yet often utterly unexpected turns of phrase, her pervasive use of plant and animal metaphors, all reveal her efforts to incorporate the lives of nonhumans into her literature.

The first-person narrator of "O Ovo e a Galinha" states: "O meu mistério que é eu ser apenas um meio, e não um fim, tem-me dado a mais maliciosa das liberdades: não sou boba e aproveito" (A Legião Estrangeira 52). Inverting the famous Kantian dictum, Lispector finds that in interspecies literature, the artist is a medium, akin to the figure of the genius so dear to Romantic thought. However, she does not believe that her task as a writer is to mediate between god and humans, as the geniuses of old, and not even to be the medium through which different human voices are expressed. The heteroglossy she aims at is much more radical than the one Bahktin identified as a key attribute of the novel (271-73). For her, the writer is a means - or a shaman - through which primordial life, flora and fauna articulate themselves in human language. She takes advantage of the freedom that artistic creation affords to enuntiate a utopian communion with plants and animals, both in life and in writing: to craft a zoophytographia.

The non-human languages that come through in Lispector's texts echo the primordial life inside us and teach us that the state of grace, whereby we commune with the world around us, is always within reach. Even though we tend to regard humanity as permanently hovering between the hither side of being and the beyond, between beast and god, between fallenness and grace (a wavering that is the source of the artistic impulse in its multiple instantiations), zoophytographic literature reveals that this dichotomy is an obfuscation. Redemption is immanent, it has happened from the beginning of time or, to put it differently, there has never been a fall, since we have always participated in 
life's becoming. In this sense, Lispector highlights a quality of all literary texts: literature is always an interspecies undertaking, in that writing necessarily reveals the others within the human. This is how we should understand the epigraph from Água Viva with which I begin the present essay: "Não vou ser autobiográfica. Quero ser "bio"” (30). "Autobiography" is tautological, in that writing, even fiction, always has the I as a point of departure. The challenge of Lispector's literary praxis is to move beyond the self as her sole reference and to become bio or, better still, zoe, thus creating a zoophytographia.

\section{Works Cited}

Bakhtin, Mikhail. "Discourse in the Novel." The Dialogical Imagination: Four Essays, edited by Michael Holquist, U of Texas P, 2002, pp. 259-422.

Ballan, Joseph. "Divine Anonymities: On Transascendence and Transdescendence in the Works of Levinas, Celan, and Lispector." Religion and the Arts, vol. 12, 2008, pp. 540-58.

Benjamin, Walter. "On Language as Such and on the Language of Man." Selected Writings. Vol. 1, 1913-1926, edited by Marcus Bullok and Michael W. Jennings, Harvard UP, 1997, pp. 62-74.

Calarco, Matthew. The Question of the Animal from Heidegger to Derrida. Columbia UP, 2008.

Gagliano, Monica, John C. Ryan, and Patrícia Vieira, editors. The Language of Plants: Science, Philosophy, Literature. U of Minnesota P, 2017.

Lispector, Clarice. Aprendendo a Viver. Rocco Digital. 2013.

—. Laços de Família. Rocco Digital. 2013.

-. Contos. Relógio D’Água, 2006.

-. Água Viva. Relógio D’Água, 2012.

-. Uma Aprendizagem ou o Livro dos Prazeres. Relógio D’Água, 2013.

-. Para não Esquecer. Rocco Digital. 2015.

-. A Paixão segundo G. H. Relógio D’Água, 2013.

-. Perto ao Coração Selvagem. Rocco, 1943.

Levinas, Emmanuel. Totality and Infinity: An Essay on Exteriority, translated by Alphonso Linguis, Martinus Nijhoff, 1979. 
- " "Transcendence and Intelligibility." Basic Philosophical Writings, edited by Adriaan Peperzak, Simon Critchley, and Robert Bernasconi, Indiana UP, 1996, pp. 149-59.

Moser, Benjamin. Why This World: A Biography of Clarice Lispector. Oxford UP, 2009.

Nascimento. Evando. Clarice Lispector: Uma Literatura Pensante. Civilização Brasileira, 2012.

Owen, Hilary. "Clarice Lispector beyond Cixous. Ecofeminism and Zen in A Paixão segundo G.H." Gender, Ethnicity and Class in Modern Portuguese-Speaking Culture, edited by Hilary Owen, Edwin Mellen, 1996, pp.161-84.

Spinoza, Benedict de. Ethics, translated by Edwin Curley, Penguin, 1996.

Vieira, Patrícia. "Phytographia: Literature as Plant Writing." Environmental Philosophy, vol. 12, no. 2, Fall 2015, pp. 205-20.

Wheeler, A. M. "Animal Imagery as Reflection of Gender Roles in Clarice Lispector's Family Ties." Critique, vol. 28, no. 3, Spring 1987, pp. 125-34.

Williams, Claire. "The Passion according to G.H. by Clarice Lispector." The Cambridge Companion to the Latin American Novel, edited by Efraín Kristal, Cambridge UP, 2005, pp. 245-57. 